を認めている，私共が分煀したマウスに腪堙と腹膜炎を

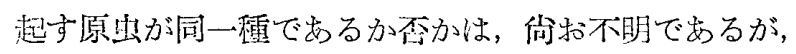

Toxoplasmaであることは愦りないと思う。しかしToー xoplasina の代表怢で努る R. H. strain と注幾分異な る上うである。

[北研]

\section{クマリン系殺鼠冎に対するVitamin $\mathrm{K}$ の影響 藤戸貞男・谷口美定 㴖柇芳郎・中島貞照}

Fujito, S., Taniguchi, Y. Tsumura, 'Y. \& Nakajima, S.: Studies on the influence of Vitamin $K$ against the coumarin rodenticide

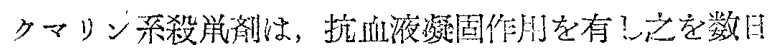

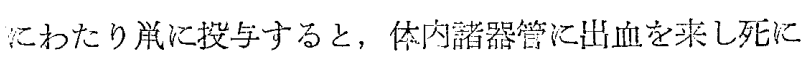
到らしめる。然るにこれ汉しVitamin K は抗出血性 作政を有し血液中のプロトロンビンを正常に維持するる

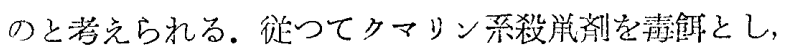

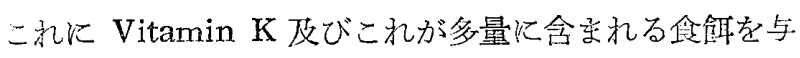

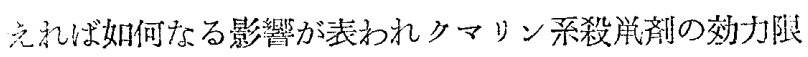
界如何を知るために本実跧を試不た。実験動物にはマウ

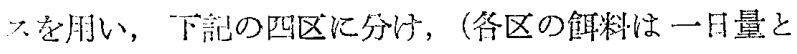
し，対照区を除いた（1) (2) (3)には 0.025\%のクマシン

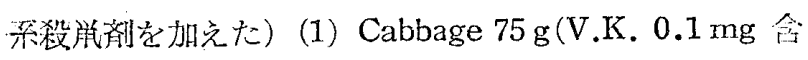
有) 与吉高 $20 \mathrm{~g}$ (V.K. $0.0025 \mathrm{mg}$ ) (2) Vitamin $\mathrm{K}_{3}$ 纵

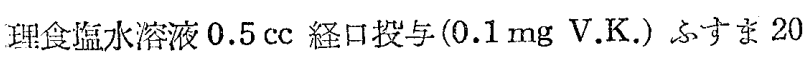
$\mathrm{g}($ V.K. $0.0025 \mathrm{mg})$ (3) 雑款 $10 \mathrm{~g}$ (V.K. $0.005 \mathrm{mg})$ 灾 学 $40 \mathrm{~g}$ (V.K. $0.004 \mathrm{mg})$ (4) 対照区…雑勃 $10 \mathrm{~g}$ (V.

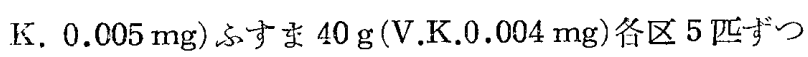
のマウスに投与し $25^{\circ} \mathrm{C}$ 内外の恒溫下で炤和 29 年 2 月 25 日から 3 月 10 日亲で実騟を継続した。投与後各区洪

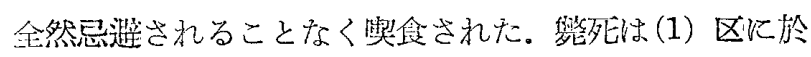

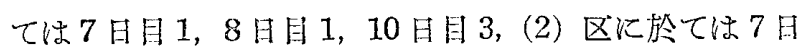
目 $2 ， 12$ 日目 12,14 日目 1,15 日目1となつている. Vitamin K 量の少ない(3) 区伦ては4日目1，5 日目 1，6日目2，7日目1となり（4）区の対照区は全期飞わ たり異常はなからた。秏死体の解剖所見は，ことごとく 证面性変化が备藏器にわたつて見られた。これらの笑験 よりVitamin K を多量に含卆食物学摄取している(1)

（2）区に於ては，(3) 区に此較して，相当な長い期間生

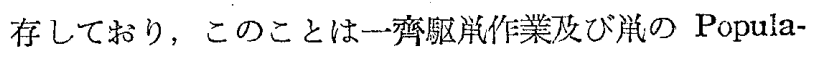
tion 調查にクマリン 采殺絾剂を朋いる場合整死体の発
見数は，その地区の訬の猺性，特にVikamin $\mathrm{K}$ 含有物 により左在さ礼るので涼ないかと思引机る。

[大阪附衛生部]

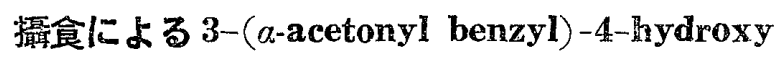 coumarin の鼠体内血中濃度站びに致死亡の閶 係(続報) 田中䇦雄田荒杢俊枝}

Tanaka, H. \& Araki, T.: Studies on the relationship between the blood concentration of 3-(a-acetonyl benzyl)-4-hydroxy coumarin and its lethal effect in rats

今船 Beckman DU Spectro-photometer により 3( -acetonyl benzyl)-4-hydroxy coumarin (以下米口解

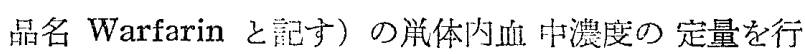

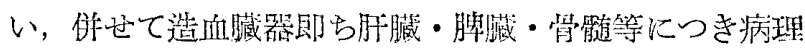
組織学的見地よりその变化てついて観察を行い，いさ」 かの知見を得たので報告する。体重 100〜200 g のラッ

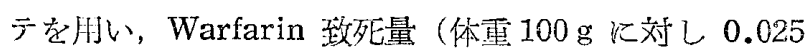
g)の $1 / 5$ 量を一匡投与量とし，メリケン粉四子に混じ完

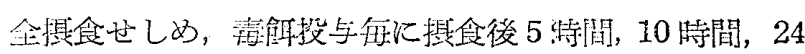

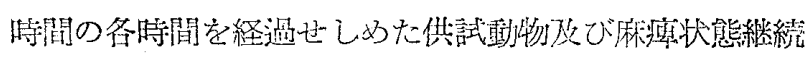

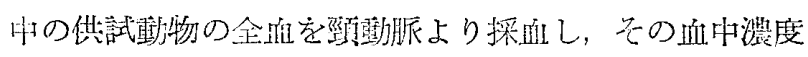
安测定した: 採䀡後の屍体は $10 \%$ \%ルマリンに固定し，

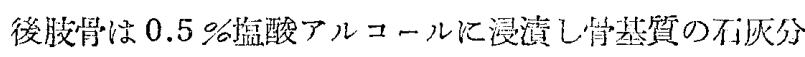

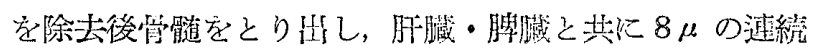

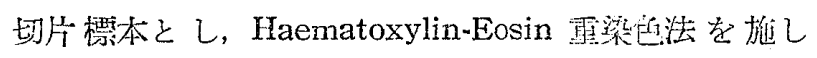
た. 漓邻投与経過及び定量結果に基づぎ等組織標本完

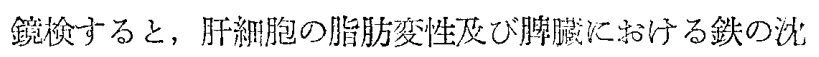
着等の諸変化がみられ, 之等は造血臟器の機能障碍機能 低下を生ぜしめると思われる。㓅結果 Warfarin 虹 濑次血中心蓄積されるのでなく，むしろ麻慣状態のもの に执いては最少量を示している. Warfarin による致死 原因に関しては，造血臟器に見られる諸変化に基づく機

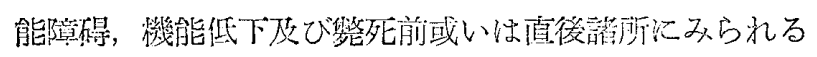
出血の原因等仙出来するものと思考され，その浴定はな

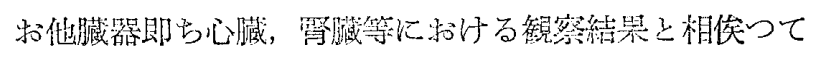
判断されるべきで交ると思考する。【大砏行立园大] 